\title{
EVALUATION OF PUBLIC FINANCE IN THE TOURISM SECTOR AT THE MUNICIPAL BUDGET LEVEL
}

\author{
LUCIE PLZÁKOVÁ \\ The Institute of Hospitality Management in Prague, Travel and Tourism Department, \\ Svídnická 506, Prague, Czech Republic \\ email: plzakova@vsh.cz
}

\begin{abstract}
The Assessment of public finance in the context of their allocation function is usually defined by criteria called. 3E: economy, efficiency and effectiveness. This approach is used for analyses of public finance at the municipal level from the point of view of revenues from local taxes in direct connection with tourism and expenditures invested into tourism sector on the other hand.

There is a total of 6,252 municipalities in the Czech Republic (2015). 903 municipalities (14.4 \%) applied a local spa or recreational stay fee and 1,387 municipalities (22.2\%) applied local accommodation capacity fee in 2015. Municipalities gained 6.8 bn. CZK from both local fees during the reporting period 2000 - 2015. Prague, the capital city, holds a dominant position as far as the volume of financial means drawn through these fees is concerned. Investments into tourism development is much lower on the local level.

The article aims to evaluate utilization of public finances in the tourism sector on local budget levels in the Czech Republic. A time series analysis, Pearson correlation coefficient, index analysis and comparison were used to achieve the goal. The primary and secondary data were subjected to the analysis.
\end{abstract}

Key words: $3 E$, local fees, tourism, municipalities, public finance

JEL Codes: H71, H72, K34, L83

DOI: 10.15611/amse.2017.20.28

\section{Introduction}

Local self-governing bodies are entitled to their own proportionate and reasonable financial resources that they may dispose of within their competencies. A portion of local communities financial resources originates from local taxes and local fees (Studnička, Tinková, 2014).

Local taxes and fees fulfil the following criteria:

- Possessive criterion- proceeds from the taxes belong to the municipality;

- Rate criterion - the municipality decides on the amount rate

- Collection criterion - the municipality must manage the tax;

- Decision criterion - the municipality decides on the basis of assessment.

Local fee is a tax of a financial character laid down by law and intended for the budget of the municipality. A regional self-governing unit (a municipality) may introduce or repeal such a tax, it may also in any manner influence the taxable income rate, the amount collected or apply any corrections as considered necessary, a condition to act within the law must be followed. To benefit from fiscal decentralization numerous conditions should be met.

Local fees have three basic functions - they are a standard flat rate payment in connection with services provided by the municipality, have a local tax character or fulfil a predominantly regulatory function. A fiscal effect is the dominant issue during the decision-making process 
on what local fee to introduce or not to introduce, it has precedence over regulatory and stimulative functions. In connection with tourism and hotel and spa industries, the most significant are two of the above mentioned local fees, in accordance with Act 565/1990 Coll., on local fees, as amended. More specifically those are a local spa or recreational stay fee (§3) and a local accommodation capacity fee $(\S 7)$. These fees have a tax character and predominantly a fiscal function. The local spa or recreational stay fee could be collected in spa localities and in places of „concentrated tourist attendance“. An accommodation provider collects this fee from his guests on behalf of the municipality. Maximum amount is $15 \mathrm{CZK}$ per person daily. The fee does not apply in instances when other than spa or recreational purpose could be determined. The amount has not been adjusted since 1991. The local accommodation capacity fee is collected in establishments designated to provide temporary accommodation for a fee; the fee does not apply to accommodations providing temporary stays for students and pupils, medical and spa facilities (unless they provide hotel services), social and charity services facilities. An accommodation provider pays the fee, maximum amount is 6 CZK per utilized bed and day. Since 1991 the amount has been adjusted twice at first from 2 to 4 , and now to $6 \mathrm{CZK}$.

\section{Theoretical framework and methodology}

The centralization or decentralization in public management issue keeps changing during time depending on economic and political stability and political system of each given country. The first half of the last century was known as a power and decision making process centralization phase, whilst during the end of the last and beginning of the current century a subsidiarity and thus decentralization is the leading principle. One of the decentralization areas is fiscal decentralization, it means transfer of selected functions and responsibilities from the central government onto regional, eventually local authorities Kee $(2003, p .4)$ adds that ,a local control over own income and expenditures is a key to efficient decentralization “. The question although is what constitutes efficient decentralization and how should it be controlled.

A typical management style in public sector used to be an administrative management style without economic management conception and strategy with clearly determined outputs and results, indicator set, control and evaluation. Current public sector management direction requires the public sector to adopt managerial methods used in business sector, so called. New Public Management (further on as NPM) and to adopt and apply a 3E concept - Effectiveness, Efficiency, Economy. Many Czech and foreign authors deal with the NPM. Among the leading creators of the NPM concept belong Aucoin (1990), Pollit (1990), and Walsh (1995). NPMs were targeted in European countries such as Great Britain, the Netherlands, Germany and Switzerland. The current foreign authors can be also named Dooren, Bouckaert, and Halligan (2010), Schedler, Proeller (2009), Van de Walle and Hammerschmid (2011), etc. Current issues of NPM research focus on the Institute of Public Finance, Fiscal Law and Law and Economics at University in St. Gallen. Czech and/or Slovak authors who address application of the NPM elements are Nemec (Wright a Nemec, 2002; Nemec a Meričková, 2008; Nemec, 2010), Ochrana (Šumpíková, Nemec a Ochrana, 2008; Nekola a Ochrana, 2009, pp. 458-474), Hendrych, Kavěna and Pavlík (2014) and others. New public management system proposed a more decentralized control of resources and exploring other service delivery models to achieve better results, including a quasi-market structure where public and private service providers competed to provide better and faster services (E.g. in health care, education). Ochrana, Půček (2014) state that the NPM could be characterized using following trends and approaches:

- decentralization 
- performance and efficiency

- selection options and competition

- customer orientation

- motivation of public service employees

- e-government

- quality of regulation improvement

- making functions of the centre healthier, so called „slim management”

- transfer of management styles from private sector

- improvement of cooperation between public and private sectors.

The NPM concept is directed, among other issues, towards productivity and efficiency that could be evaluated according to $3 \mathrm{E}$ principles. This term comes up mostly in connection with financial control and audit. For the purpose of Czech public management, the $3 \mathrm{E}$ concept is governed by Act 320/2001 Coll., on financial control in public management, as amended. The Act defines basic $3 \mathrm{E}$ concepts as follows

Economy -such use of public means to ensure completion of defined tasks with the lowest expenditures while complying with requirements for appropriate quality of the tasks,

Efficiency -such use of public means to ensure the widest possible range, quality and benefit of the tasks in comparison with the volume of means used to implement the tasks,

Effectiveness-such use of public means to ensure optimal level of goals reached through the task completion.

With regards to this issue Vodáková (2013) also states risks in connection with 3E evaluation. In the case of economy, it could be waste, overpaying, unnecessary luxuries; in the case of efficiency it could be loses, sub-optimal input-output ratio, slow program and externalities realization; risks in connection with effectives might be a flawed concept or insufficiencies in management She also states that „A Czech public sector still deals with the issue that whilst on legislative level the $3 \mathrm{E}$ concept is set up in general terms and managers are mostly familiar with it, in practice economic systems management is often not consistent with the three above described principles but is more or less limited to monitoring budgetary appropriation" (Vodáková, 2013, p.21).

Evaluation of public finances in the tourism sector budgets of municipalities is based on primary and secondary data analyses. The revenue side of budgets (for the purpose of this study) is comprised of revenue from local spa and recreation fee (LF-SR) and local accommodation capacity fee (LF-AC). The expenditures side expenditures budgeted under Sec. 2143 Tourism Primary data were obtained through questionnaires and interviews conducted in 2013. Total of 62 municipalities were selected for the questionnaire research, the total of their income from LF-AC was 68,5 \% and 76,5 \% from the LF-SP. Self-government, private sector (accommodation providers) and professional representatives (Czech Republic Hotel and Restaurants Association) gave the interviews. Secondary data were drawn from publicly accessible Czech Statistical Office resources, from the www.rozpocetobce.cz portal, and from the Ministry of Finance MONITOR database. A time series analysis, Pearson correlation coefficient, index analysis and comparison were used to achieve the results.

\section{Results}

Out of a total number of 6,252 municipalities in the Czech Republic in 2015, 947 municipalities $(15,1 \%)$ were collecting the local recreation or spa fee. Nevertheless, out of the 947 municipalities 44 showed zero income. The rather high number of municipalities with zero income from local charges has probably been caused by errors when the Evaluation of budgetary implementation with GORDIC program assistance was not filled out properly by local authorities. If this budgetary item does not apply to a municipality then in compliance 
with the CR Ministry of finance instructions the municipality does not complete the line for this budgetary item. But in case the municipality ignores these instructions and fills in a zero, then the item becomes active and enters into the statistic. That causes a minor distortion/misstatement. 1,491 municipalities $(23,8 \%)$ collected the local accommodation capacity fee. A total of 104 municipalities showed zero income at the end of 2015. Prague, the capital city, holds a dominant position as far as the volume of financial means drawn through these charges is concerned. (Table 1). Total revenues from the LF-SP increased by 52,6\%, from the LF-AC by $270 \%$ during the monitored period, in case of Prague we are talking about revenue increase from the LF-SP by $68 \%$ and the increase from the LF-AC was 4,5 times bigger.

Table 1: Volume of fees LF-SP a LF-AC collected in the Czech Republic and in the capital Prague between 2000 and 2015 in CZK

\begin{tabular}{lllll}
\hline Year & $\begin{array}{l}\text { Czech Republic } \\
\text { LF-SP }\end{array}$ & LF-AC & Capital Prague \\
& $213,990,740$ & $64,762,020$ & $88,803,830$ & LF-AC \\
\hline $\mathbf{2 0 0 0}$ & $326,569,583$ & $239,546,280$ & $148,985,529$ & $119,421,736$ \\
$\mathbf{2 0 1 5}$ & & & & \\
\hline
\end{tabular}

Source: Author's own work, using MONITOR data, 2017.

Another analysis consists of 7 categories of municipalities with significant and/or unique tourism destinations. Prague and Brno form an independent category. Another category are UNESCO World Heritage localities without Prague and Brno. Brno is exempt because of its dominant position in the MICE (meeting, incentive, conference, event) sector, it is in accordance to an amended Act 565/1990 Coll., on local fees, exempt from the LF-SP charge duties. Another three categories are formed by 10 significant Czech and Moravian spas, mountain resorts and tourist destinations in close proximity to water bodies. Five large cities with varied tourist offerings form the last category - Hradec Králové, Plzeň, České Budějovice, Mladá Boleslav (MICE sector) and Ostrava. In total 49 municipalities were analyzed, as performance indicators we followed their revenues from the local accommodation capacity fee and local spa or recreational stays fee, tourism expenditures from the municipalities' budgets under Sec. 2143 Tourism in a budget structure, and a number of overnights (performance indicator).

The development of LF-SP revenues show a slightly increasing trend in the 2000-2015 monitored period with categories Brno, UNESCO, places in close proximity to water bodies and large cities. Mountain resorts, spas and the capital Prague display fluctuations during the monitored periods with a generally increasing trend. But spas are the only category where incomes from this fee keep declining since 2011. All the categories show unambiguously increasing trend in general in the LF-AC revenues with a much higher growth rate, that has been caused by a double increase of the possible maximum rate of the charge in 2004 and 2010 to the current maximum charge of 6 CZK per person and day. Spas again display a decline during the last three years of monitoring and large cities do in 2015. Table 2 with Pearson's correlation coefficient provided shows whether this development corresponds with development of overnights numbers in given categories. The relationship between revenues from LF-SP and numbers of overnights is significant $(0.01$ level) in the Prague, spas and UNESCO categories. In large cities and Brno instances this insignificant and low indicator dependency is possible to explain considering the type of tourism occurring in these places - it is a business tourism. But mountain resorts and localities in close proximity to water bodies fulfill mostly recreational and spa functions, and the indicator dependency should be higher. There is a high proportion of individual accommodation facilities whilst the number of 
overnights indicator displays only numbers of overnights in public accommodation facilities. Another reason could be discovered using local fee revenues where precisely these individual accommodation facilities and apartment rentals show an incredibly low bed capacity occupancy, almost unrealistic from a business proprietor point of view. It would be suitable to analyze revenue from the LF-AC in the same manner but a suitable indicator clearly seems to be bed utilization. The Czech Statistical Office (CZSO) publishes this indicator only on regional levels, which is applicable for Prague only where the correlation coefficient shows a dependency level of 0.715 .

Table 2: Pearson correlation coefficient between the LF-SP revenues and number of overnights in public accommodation facilities

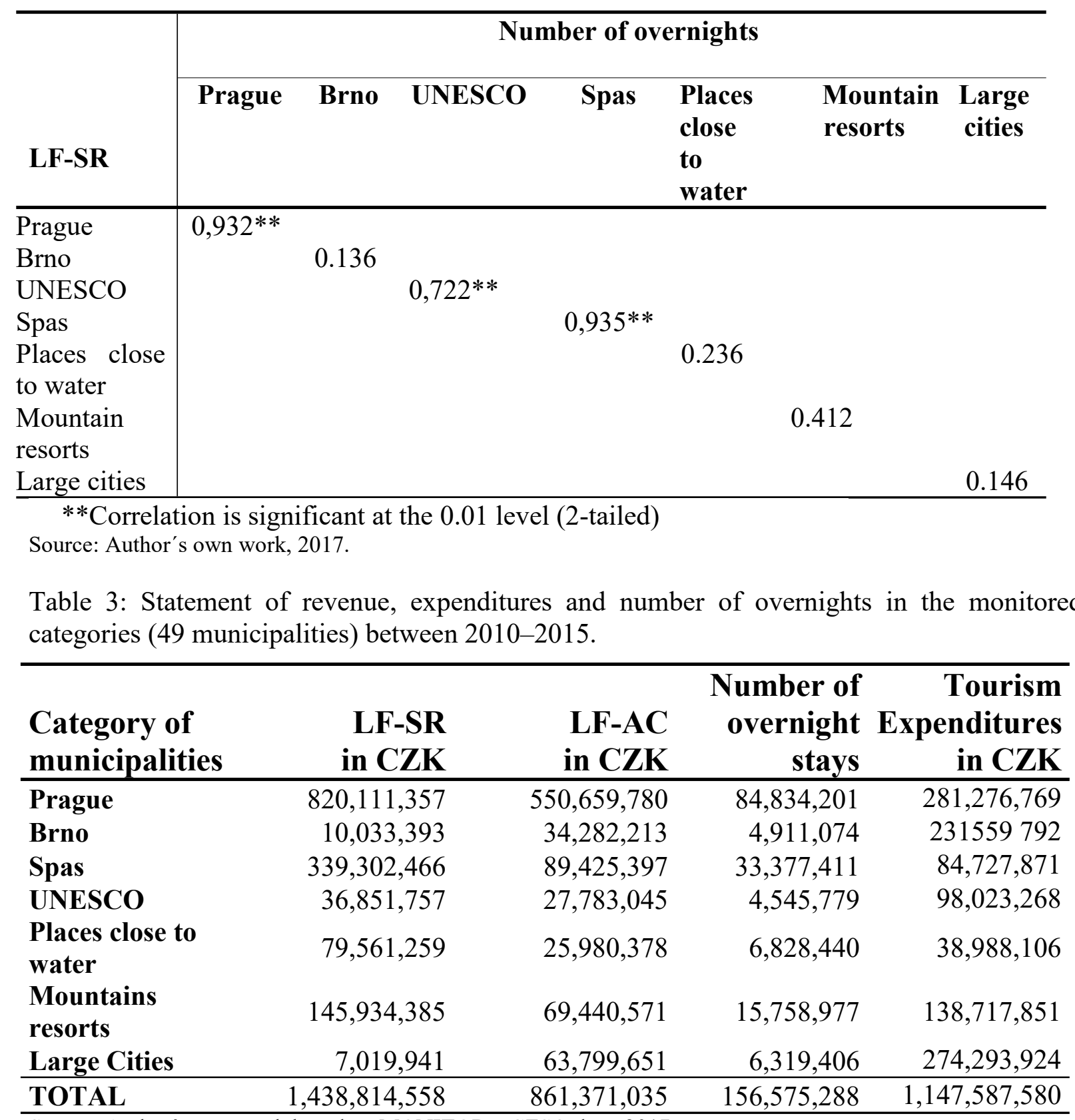

Source: Author's own work based on MONITOR a CZSO data, 2017.

If we proceed to the revenue and expenditures analysis then data in Table 3 should be suitable for our primary assessment. The revenue is comprised from both local fees in direct 
connection to tourism and the expenditures are finances that the municipalities reported during the monitored period ${ }^{1} 2010-2015$ in their budgets in Sec. 2143 Tourism. During the six monitored years, these 49 municipalities received 2,300,185,593 CZK from both local fees and their current and capital expenditures within the scope of Sec. Tourism amounted to $1,147,587,580 \mathrm{CZK}$, that is $49.9 \%$. The total of realized overnights in public accommodation facilities in the monitored municipalities was 156.5 thousand.

Using a more detailed look into individual municipality categories it is possible to state that expenditures into tourism decrease in time in case of the capital Prague and spa localities, Brno show an increasing trend, and the rest of the categories show a fluctuating trend (Graph 1). Increased expenditures in Sec. 2143 Tourism can be viewed in some categories (Prague, large cities, spas) during periods of European structural funds allocations i.e. in our case between 2010-2013.

Figure 1: Development of tourism expenditures (Sec.2143) in monitored categories from 2010 till 2015

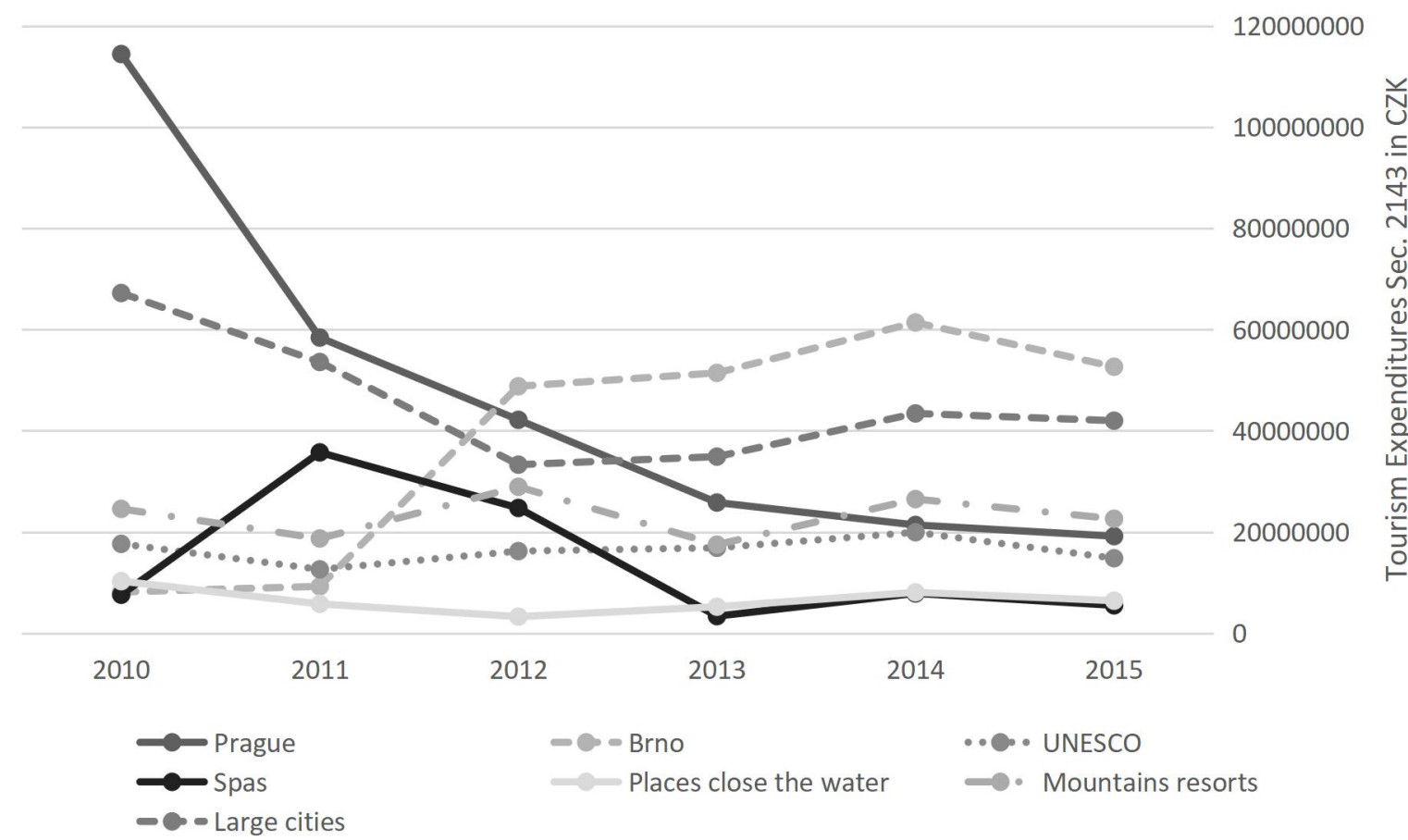

Source: Author's own work, 2017.

Current expenditures exceed capital expenditures volume supporting tourism and more than $44 \%$ of current tourism expenditures are used in a non-investment transfers to subjects accounting entry (contributory organizations, private entities, etc.). A more interesting information than the tourism expenditures development itself is the ratio of expenditures to revenues from local fees with direct relationship to tourism. An inquiry comes up here about whether the municipalities invest the tourism revenues back into its development. The following Table 4 shows the reinvestment rate (current and capital expenditures) in individual categories. Prague, spas, places in vicinity of water bodies and mountain resorts invested into tourism development between 2010 and 2015 less than they gained from local fees. These categories invest only negligible, minute amounts per one overnight stay. Spas invest the least amount into one overnight stay in public accommodation facilities. On the other hand, Brno,

\footnotetext{
1 The Ministry of Finance Monitor database has been providing data since 2010.
} 
UNESCO locations and large cities invest into tourism development support more than they gain from local fees, one overnight stay costs them tens of Crowns, as seen in Table 4. In cases of Brno and the large cities the revenues from local charges are lower (the ratio of expenses to revenues is higher) due to a large proportion of business tourism since these tourism participants are exempt from charge paying duties. Pearson's correlation coefficient points to a very strong indirect dependence between tourism expenditures and a number of realized overnights in public accommodation facilities in case of Prague and medium indirect dependence in the large cities category. On the contrary, a direct strong and medium strong dependence is displayed in Brno and spa categories. We could claim that expenditures in support of tourism do influence number of overnights in spa destinations and in Brno. In Prague expenditures from the city budget have no influence on numbers of realized overnight stays. In support of this conclusion it would be necessary to determine exactly for what activities, services and events were these financial resources used.

It is interesting to note that there are cities that for the monitored period have not recorded a single expenditure in Sec. 2143 Tourism. One of them is e.g. Telč, a UNESCO city and another one is the most prominent and famous Czech spa town of Karlovy Vary that show an expenditure in Sec. 2143 only once in the amount of 2 million CZK in 2011.

Table 4: Ratio of tourism expenditures to local fees revenues in direct relationship to tourism, level of expenditures per one overnight stay and Pearson's correlation coefficient for expenses and number of overnights indicators

\begin{tabular}{lrrr}
\hline $\begin{array}{l}\text { Category of } \\
\text { municipalities }\end{array}$ & $\begin{array}{r}\text { Ratio of } \\
\text { expenditures } \\
\text { to revenue }\end{array}$ & $\begin{array}{r}\text { Expenditures per } \\
\text { one overnight (in } \\
\text { CZK) }\end{array}$ & $\begin{array}{r}\text { Pearson coefficient } \\
\text { (expenditures x overnights) }\end{array}$ \\
\hline Prague & 0.205 & 3.32 & -0.914 \\
Brno & 5.225 & 47.15 & 0.872 \\
Spas & 0.198 & 2.54 & 0.781 \\
UNESCO & 1.517 & 21.56 & 0.414 \\
Places close the & 0.369 & 5.71 & 0.036 \\
water & & & \\
Mountains & 0.644 & 8.80 & 0.346 \\
resorts & 3.873 & 43.41 & -0.598 \\
Large Cities & & &
\end{tabular}

Source: The author's work, 2017.

There are other sections within budget structures of municipalities where expenditures connected to tourism development could be reported, and municipalities often use that as their argument. We are talking about Sec 2142 Accommodations and catering, and Secs 33.., used to report expenditures for culture. Sec 2142 analysis showed only two municipalities in the framework of our categories that had recorded any financial appropriations; municipality of Lednice with 135 CZK and Pasohlávky with 14.1 million CZK in 2010-2013 invested into accommodations and catering (co-financing of a project from Southeast regional operational program). Municipalities show much higher expenditures in cultural area than the area of tourism. Out of the culture related sections, we chose namely Sec 3311 Theater activities, 3312 Musical activities, 3315 Museum and gallery activities, 3317 Exhibit activities in culture, and 3322 Prserevation and maintenance of cultural heritage.

Based on budget implementation analysis of selected cities in the framework of monitored categories and based on a KPMG study from 2012 „Tourism expenditures in the CR analysis: public funding resources used to support tourism", the author set coefficients in individual 
categories representing the ratio of expenditures into culture with direct impact on tourism. The lowest expenditures into culture with direct impact on tourism have municipalities in close proximity to water bodies and mountain resorts, which is understandable, considering the forms of tourism and primary motivation of visitors. The capital Prague, UNESCO locations and Brno show the highest appropriation of finances for cultural items with strong potential of utilization in tourism. High spending in the large cities category is the consequence of preparations and realization of Plzen - European city of culture 2015 project. If we took these specific expenditures for culture and added them to tourism expenditures under Sec 2143 and compared them to revenues from local fees, then the expenses-income ratio would increase significantly. Nevertheless, there are still three categories left where even whilst adding expenses for culture a balanced expenses-income ratio would not be achieved. It is important to note here that we work with revenues from the two local fees only, and that municipalities receive financial means to support culture from other resources as well.

Table 5: Expenditures in CZK for cultural matters (theaters, music, museums, and galleries, exhibits, protection and maintenance of cultural heritage) between 2010 and 2015.

\begin{tabular}{|c|c|c|c|}
\hline $\begin{array}{l}\text { Category of } \\
\text { municipalities }\end{array}$ & $\begin{array}{r}\text { Expenditures from } \\
\text { selected cultural sections } \\
\end{array}$ & Coefficient & $\begin{array}{r}\text { Expenditures for } \\
\text { cultural matters in } \\
\text { relationship with } \\
\text { tourism }\end{array}$ \\
\hline Prague & $5,342,046,922$ & 0.45 & $2,403,921,115$ \\
\hline Brno & $4,734,437,303$ & 0.20 & $946,887,461$ \\
\hline Spas & $381,671,847$ & 0.26 & $99,234,680$ \\
\hline UNESCO & $2,002,238,794$ & 0.45 & $901,007,457$ \\
\hline $\begin{array}{l}\text { Places close the } \\
\text { water }\end{array}$ & $46,800,657$ & 0.10 & $4,680,066$ \\
\hline $\begin{array}{l}\text { Mountains } \\
\text { resorts }\end{array}$ & $604,229,525$ & 0.08 & $48,338,362$ \\
\hline Large Cities & $6,436,048,355$ & 0.16 & $1,029,767,737$ \\
\hline
\end{tabular}

Source: The author's work, 2017.

When assessing 3E principals' implementation it is imperative to be familiar with objectives and specific goals the organization/municipality wants to achieve. In our case those would be the goals within tourism sphere in the monitored municipalities. Creation of conceptual and strategic documentation on tourism development in municipalities is not currently obligatory in the CR. Municipalities owning such a documentation are rare, e.g. Český Krumlov, Lipno n. V. Activities and goals in support of tourism on local level should aim towards reaching the goals on regional and then jointly on national levels. Together they should lead towards implementation of The State Policy on Tourism of the Czech Republic 2014-2020. Plzáková (2013) states that "Interdependence of strategic documentation on national, regional and local levels is not reaching levels able to provide maximum synergy effect to implement priorities supported by public resources." Nevertheless, a survey research conducted in 2015 (Plzáková and coll., 2015) suggests that $94 \%$ of participating municipalities consider tourism to be a developmental priority. Municipality officials consider the main reasons for supporting tourism in their places to be employment and new work opportunities including private businesses, municipality development and increase of revenues, impact on historic buildings and landmarks, and development of spas and balneal facilities. Residents gave the assessment of tourism in their villages an average grade of 1.89, which could be viewed as a good result. 
Table 6: Total proportion of expenditures for tourism and culture (items related to tourism) to revenues from local fees during 2010-2015 in selected categories of municipalities.

\begin{tabular}{lrrr}
\hline $\begin{array}{l}\text { Category of } \\
\text { municipalities }\end{array}$ & Income & Expenditures & $\begin{array}{r}\text { Ratio of } \\
\text { expenditures to } \\
\text { incomes }\end{array}$ \\
\hline $\begin{array}{lrrr}\text { Prague } \\
\text { Brno }\end{array}$ & $1,370,771,137$ & $2,685,197,884$ & 1.96 \\
Spas & $44,315,606$ & $1,178,447,253$ & 26.59 \\
UNESCO & $428,727,863$ & $183,962,551$ & 0.43 \\
Places close to & $64,634,802$ & $999,030,725$ & 15.46 \\
water & $105,541,637$ & $43,668,172$ & 0.41 \\
Mountains & $215,374,956$ & $187,056,213$ & 0.87 \\
resorts & $70,819,592$ & $1,304,061,661$ & 18.41 \\
Large cities & $2,300,185,593$ & $6,581,424,459$ & 2.86 \\
\hline Total & & & \\
\hline Sotal
\end{tabular}

Source: The author's work, 2017.

A general goal of tourism destinations could, in a rather simplistic manner, be an increase of overnight stays in accommodation facilities in a given area. If we intend to evaluate public finances economy of use, we could go back to Table 4 that clearly shows the level of public resources applied to support one overnight in a public accommodation facility. The most efficient use of public finances could be captured in Prague and in spa locations, but only with no other knowledge available. In spas stays and treatments in spa facilities are supported by medical insurance schemes, by the Ministry of Health, but also by individual municipalities in case of municipal spa such as Třeboň. Prague as a tourism destination with its highest potential stands out. Prague is a so-called Czech Republic key product and compared to other destinations, economies of scale are applied to financing matters in support of tourism. In this aspect, it is very difficult to assess effectiveness, since the "highest possible range" of objectives to meet is not known. What is thus the optimal bed capacity rate of accommodation facilities in a given municipality? The answer to this question gets influenced by many additional factors in each municipality, e.g. wastewater treatment plant capacity, municipal waste collection capacity, public transport capacity, and by other public services such as security, availability of medical services, etc. Whilst evaluating the effectiveness we might use data featuring level of tourism expenditures development in the municipalities and number of overnights development. Unfortunately, it appears that the number of overnights does not depend on the rate of appropriations committed to tourism development from local budgets of the municipalities. In Prague, spas, and large cities the correlation coefficient is actually negative, in mountain resorts and destination in proximity to water bodies it is lower than 0.3. In the case of UNESCO locations, it reaches a level of 0.41 (Table 4).

\section{Conclusion}

The goal of this article was to evaluate utilization of public finances in the tourism sector on local budget levels in the Czech Republic. For the purpose of this evaluation we established a total of 8 categories containing 49 municipalities (Prague, Brno, spas, municipality on UNESCO register, mountain resorts, municipalities in proximity to water bodies and 5 large cities). The categories arise from types of tourism and primary motivation to visit these places. 
Direct revenues from tourism flowing into local budgets are the revenues from local fees. In direct connection to tourism those are the local spa or recreational fee and the local accommodation fee. In the last 16 years, the 49 monitored municipalities have procured over 5 billion CZK into their budgets. More than half of the revenues flowed into the capital city of Prague budget.

Direct tourism expenditures are recorded in the municipality budgets in Sec 2143 Tourism. The monitored municipalities showed in this section during 2010-2015 a total of 1,147 billion CZK. In absolute terms, Prague, Brno, and large cities displayed the most expenditures in their budgets, but in relative terms e.g. Prague invested only $20.5 \%$ out of the collected local charges into tourism. Expenditures not reaching revenue levels from local fees were incurred also in the spa $(19,8 \%$,), destinations in proximity to water bodies $(36,9 \%)$ and mountain resort $(64,4 \%)$ category. On the other hand, expenditures exceed revenues in Brno, UNESCO localities and in large cities. In case of Brno and large cities, the reasons are lower recovery rate from spa or recreational fee that do not apply to business travelers, and also preparations and realization of the Plzen - European capital of culture 2015 project. Current expenditures exceed capital ones and in terms of accounting items "non-investment transfers to entities" are significantly dominant. This means financing of contributory organizations and private entities performing mostly tourist information centre or destination management organization functions. Other expenditures that could be partially connected to support of tourism are expenditures into cultural matters.

During the 2000-2015 period 370.5 million overnights were realized in public accommodation facilities in the monitored municipalities. The performance indicator "number of overnights in public accommodation facilities" substitutes non-existence of strategic documentation in tourism in most of the monitored municipalities. Maximization of this performance indicator was accepted as a general objective for the $3 \mathrm{E}$ implementation assessment. Calculation of expenses for one realized overnight stay could be used to evaluate the economy of using public finance in tourism sector. The lowest level of economy are shown in Brno, large cities and UNESCO locations. It is not possible to assess efficiency without particular goals since the "highest possible range" of objectives to meet is not known. It applies to the ability to determine the optimal bed capacity rate of accommodation facilities in a given municipality. The effectiveness assessment of public finances usage expressed by tourism expenditures development in relation to number of overnights development points to a fact that in the monitored municipalities the number of overnights is not in direct positive relation to the amount of public expenditures incurred to support tourism development.

Another step within these monitored issues might be taken in a direction towards realization of tourism expenditures, towards proposal to define ,tourism expenditure „on local level, and last but not least, it would be interesting to follow legislative process of amendment to Act 565/1990 Coll. on local fees, in which case legislative changes were proposed and certified methodology has been drawn up under the leadership of the author.

\section{Acknowledgements}

The outcomes submitted in this article are based on realized projects „Local charges collection analysis in relation to capacity and efficiency of accommodation and spa facilities in the Czech Republic“ (contracting authority: CzechTourism), „Impact of local charges on tourism development" a „Modification proposal for local fees in direct connection to" (contracting authority: Ministry for Regional Development of the Czech Republic). 


\section{References}

[1] AUCOIN, P. 1990. Administrative Reform in Public Management: Paradigms, Principles, Paradoxes and Pendulums. Governance., vol. 3, no. 2, pp. 115-137.

[2] DOOREN, W., BOUCKAERT, G., HALliGAN, J. 2010. Performance management in the public sector. Routledge, ISBN: 978-0-415-37105-6

[3] HENDRYCH, D., KAVĚNA, M., PAVLÍK, M. 2014. Správní věda. Teorie veřejné správy. Praha: Wolters Kluwer. ISBN: 978-80-7478-561-0

[4] Kee, J., E. 2003. Fiscal Decentralization: Theory as Reform. Working paper, The Gorge Washington University. [cit. 06-03-2017] https://www2.gwu.edu/ clai/working_papers/James\%20Kee\%20Fiscal\%20Decentralizati on\%20paper\%202003.pdf

[5] NEKOLA, M., OCHRANA, F. 2009. Economic Evaluation of Public Programs. Journal of Economics. vol. 57, no. 5, pp. 458 - 474.

[6] NEMEC, J. 2010. New public management and its implementation in CEE: what do we know and where do we go? NISPAcee Journal of Public Administration and Policy. vol. 3, no.1, pp. 31-52.

[7] NEMEC, J., MERICKOVA, B., OCHRANA, F. 2008. Introducing benchmarking in the Czech Republic and Slovakia: Processes, problems and lessons. Public Management Review. vol. 10, no. 5, pp. 673-684.

[8] OCHRANA, F., PƯČEK, M. 2012. Dosahování úspor a omezování plýtvání ve veřejném sektoru. 1. vydání. Praha: Wolters Kluwer ČR, 228 s. ISBN: 978-80-7357-909-8

[9] PLZÁKOVÁ, L. 2013. Financování rozvoje turismu v regionech ČR s návazností na strategické dokumenty. Hradec Králové: Univerzita Hradec Králové. s. 104-110, 369 s. ISBN 978-80-7435-250-8.

[10] PLZÁKOVÁ, L., STUDNIČKA, P., TITTELBACHOVÁ, Š. 2015. Vliv místních poplatků na rozvoj cestovního ruchu. Výzkumná zpráva. Praha. Ministerstvo pro místní rozvoj ČR. $103 \mathrm{~s}$.

[11] POLLITT, C. 1990. Managerialism and the Public Services: The Anglo-American Experience. Basil Blackwell, Cambridge, MA.

[12]STUDNIČKA, P., TINKOVÁ, V. 2014. Problematika místních poplatků ve vztahu k cestovnímu ruchu. Jihlava, 2014. s. 227-232, 6 s. ISBN 978-80-87035-87-0.

[13] SCHEDLER, K., PROELLER, I. 2009. New Public Management. UTB Stuttgart, ISBN10: 3825221326

[14] ŠUMPÍKOVÁ, M., NEMEC, J., OCHRANA, F. 2008. Czech and Slovak lessons for public administration performance evaluation, management and finance. Ekonomický časopis. no. 04, pp. 353-369.

[15]VAN DE WALLE, S., HAMMERSCHMID, G. 2011. The impact of the new public management: Challenges for coordination and cohesion in European public sectors (review essay). Halduskultuur - Administrative Culture, 12(2): 190-209

[16]VODÁKOVÁ, J. 2013. Nástroje ekonomického řízení ve veřejném sektoru. Walters Kluwer, ISBN: 978-80-7478-324-1 
[17]WALSH, K. 1995. Public Services and Market Mech-anisms: Competition, Contracting and the New Public Management. London: Macmillan.

[18]WRIGHT, G., NEMEC, J. 2002. Public Management in the Central and Eastern European Transition: Concepts and Cases. Bratislava: NISPAcee. 